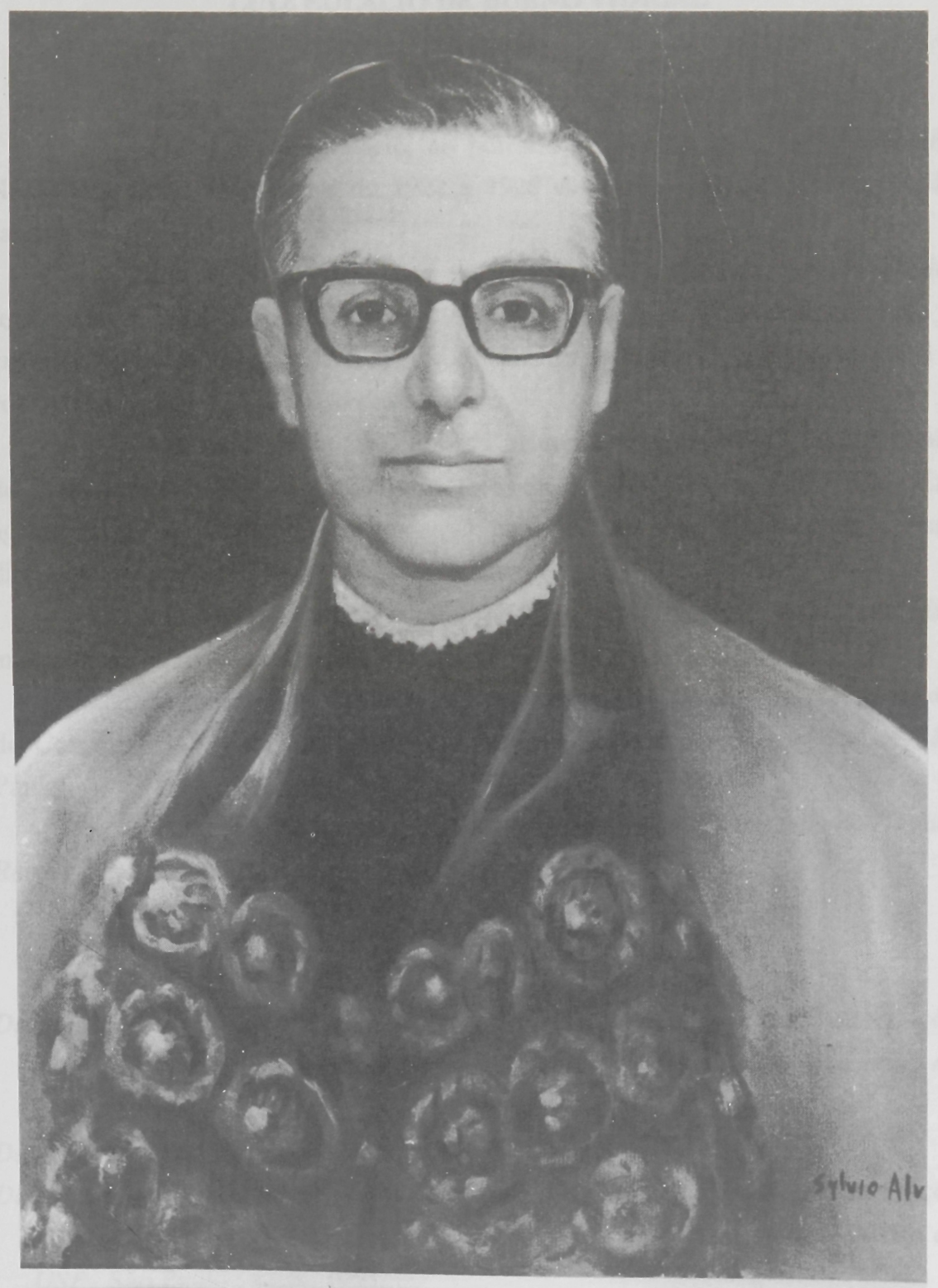

OWE L.E.BUENO VIDIGAL P 



\section{LUIZ EULÁLIO DE BUENO VIDIGAL}

(1963-1966)

Nasceu em São Paulo a 4 de fevereiro de 1911.

Fez o curso primário, no período de 1918 a 1922, no Ginásio de Nossa Senhora do Carmo, e de 1922 a 1928 cursou o Ginásio de Estado, da capital.

Em 1928 matriculou-se na Faculdade de Direito de São Paulo, recebendo o grau de bacharel em 1932. Foi então professor de Geografia e exerceu depois os cargos de inspetor do ensino secundário, secretário geral e consultor jurídico do Sindicato dos Bancos.

Em outubro de $1940 \mathrm{fez}$ seu primeiro concurso para livre-docente de Direito Judiciário Civil e, aprovado, recebeu o grau de doutor em Direito. Em agosto de 1953, participou de concurso para professor catedrático da mesma disciplina, sendo classificado em primeiro lugar.

No período de 1963 a 1966 foi diretor da Faculdade de Direito. Em março de 1973, foi-lhe conferido o título de professor emérito.

É conselheiro da Sociedade Brasileira de Cultura Inglesa, membro do Conselho da Ordem dos Advogados e do Instituto dos Advogados de São Paulo.

Possui vários artigos publicados na Revista da Faculdade de Direito, Revista dos Tribunais e Revista Forense.

\section{Obras Publicadas}

Da execução direta das obrigações de prestar declaração de vontade: dissertação para concurso à cadeira de direito judiciário e civil da Faculdade de Direito da USP São Paulo : Revista dos Tribunais, 1940.

Da ação rescisória dos julgados. São Paulo : Saraiva, 1948.

Da imutabilidade dos julgados que concedem mandado de segurança: dissertação de concurso à cadeira de direito judiciário e civil da Faculdade de Direito da USP. São Paulo : s.c.p., 1953.

Do mandado de segurança. São Paulo : s.c.p., 1953. 
Existe direito de ação? Revista de Direito Processual Civil, São Paulo, v. 5, p. 712, 1962.

Direito processual civil. São Paulo : Saraiva, 1965. 